\title{
A LOHAS SZEGMENS MÉRETE ÉS JELLEMZÓI MAGYARORSZÁGON
}

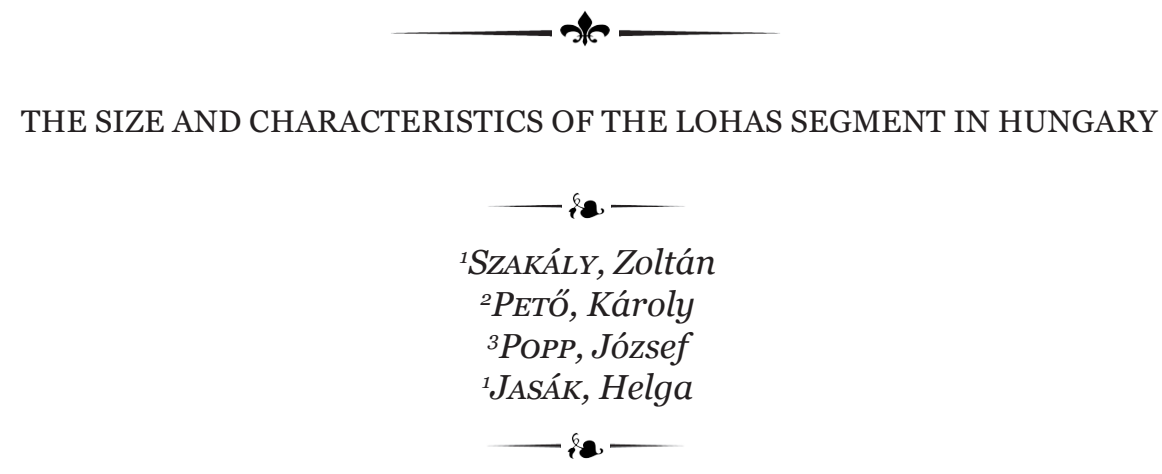

\author{
${ }^{1}$ Debreceni Egyetem, Gazdaságtudományi Kar, Marketing és Kereskedelem Intézet \\ (University of Debrecen, Faculty of Economics, Institute of Marketing and Commerce) \\ ${ }^{2}$ Debreceni Egyetem, Gazdaságtudományi Kar, Vidékfejlesztés, Turizmus- és Sportmenedzsment Intézet \\ (University of Debrecen, Faculty of Economics, Institute of Rural Development, Tourism and Sport Management) \\ 32Debreceni Egyetem, Gazdaságtudományi Kar, Ágazati Gazdaságtan és Módszertani Intézet \\ (University of Debrecen, Faculty of Economics, Institute of Sector Economics and Methodology) \\ H-4032 Debrecen, Böszörményi út 138. \\ e-mail: szakaly.zoltan@econ.unideb.hu
}

G

Until the 1990s, those exchange processes were in the focus of marketing in which the producers had the bargaining power in their hands. After realizing the limited sources and the natural challenges at the beginning of the twenty-first century, today marketing experts are interested in global issues like sustainable development and sustainable consumption. The aim of our research was to define the size of the Hungarian LOHAS consumer group by analysing its lifestyle based on sustainable values. This has been achieved in three steps. At first, the appearance of sustainable values was analysed using factor analysis. Secondly, we made the value-based lifestyle segmentation of the Hungarian consumers with the help of k-means analysis, and finally, with further segmentation, we estimated the size of the consumer group that is the most devoted to LOHAS values. In order to achieve the set objective, a nationwide representative questionnaire-based survey was carried out involving 1000 people in Hungary. During the value-orientated research, 25 lifestyle statements were drawn up. The 25 statements were grouped around 5 aspects which were the following: environmental consciousness, health consciousness, ethical values, authentic values and individualism. Results reveal that in the value order of Hungarian consumers, the characteristics showing in the direction of sustainability are present and they are separated in six value categories. They are individualist values, authentic values, environmental consciousness, ethical (competence) values, health consciousness and ethical (corporate) values. From among the value dimensions, authentic values, health and environmental consciousness, as well as ethical corporate behaviour are especially important to Hungarian consumers. According to our results five value-based segments could be separated which are Uninvolved elderly people (16.4\%), Young trend followers (32.1\%), Young environmentally conscious people (18.6\%), Ethical traditionalists (22.6\%) and also Disappointed pessimists (10.3\%). The biggest cluster, the group of Young trend followers, reflects the characteristics of the LOHAS consumers' lifestyle the most. Yet, this segment cannot entirely be regarded a consumer group devoted to LOHAS values. The biggest heterogeneity can be observed based on the ethical (competence) values of Young trend followers, and a further segmentation of this group was considered necessary to be able to ascertain the rate of the most devoted LOHAS consumers. The third sub-cluster that overestimates the ethical (competence) statements the most can be identified with the LOHAS consumer group. Based on the results of our research, their rate is $8.7 \%$ within the Hungarian population. Further research is necessary to find out whether the situation of value orientation in the other Eastern European countries is similar to that in Hungary, where the social and the cultural backgrounds show many similarities.

KuLCSSZAVAK: fenntarthatóság, szegmentálás, Fiatal trendkövetők, LOHAS
KEYWORDS: sustainability, segmentation, Young trend followers, LOHAS 


\section{BeVEZETÉS - INTRODUCTION}

Az 1990-es évekig a marketing fókuszában azok a cserefolyamatok álltak, amelyekben a hatalom birtokosa a termelő volt [19]. Az erőforrások korlátozottságának és a környezeti kihívásoknak (pl. éghajlatváltozás, ózonréteg elvékonyodása, talajpusztulás, elsivatagosodás, levegő- és vízszennyezés, ivóvízhiány) a felismerésével, a harmadik évezred elején olyan globális kérdések foglalkoztatják a marketing szakembereket, mint a fenntartható fejlődés és a fenntartható fogyasztás $[1 ; 4 ; 7 ; 16]$. A fenntarthatóság előtérbe kerüléséhez nagymértékben hozzájárult az előbbiekben említett tényezők mellett az egyének egészségtelen életmódjából fakadó civilizációs betegségek rohamos terjedése [17], melyek a WHO (2012) adatai szerint a halálozások 63\%-áért felelősek [21]. Az 1992-ben Rio de Janeiro-ban megrendezett ENSZ Környezet és Fejlődés Konferencián (UNCED) újragondolták a fenntarthatóság kérdését: a fogyasztás szempontjából közelítették meg, és bevezették a fenntartható fogyasztás fogalmát $[5 ; 6 ; 11 ; 12]$, mely napjaink egyik, a fogyasztói szokásokat befolyásoló megatrendje a fejlett országokban [20; 22]. Mindez alátámasztja a fenntartható fogyasztás iránt elkötelezett fogyasztói csoportok vizsgálatának aktualitását és szükségszerüségét [13].

Kutatásunk célja a fenntartható értékrend szerinti életstílus elemzésével meghatározni a magyarországi LOHAS fogyasztói csoport nagyságát, melyet három lépésben valósítottunk meg. Elsőként a fenntartható értékrend hazai megjelenését vizsgáltuk faktorelemzés segítségével. Ezt követően elvégeztük a magyar fogyasztók értékrend alapú életstílus szegmentációját k-means klaszterezési eljárás segítségével, végül pedig további szegmentációval megbecsültük a LOHAS értékek iránt legelkötelezettebb fogyasztói csoport nagyságát. Célkitüzésünk volt továbbá, hogy eredményeinket összehasonlítsuk Rácz (2013) azonos módszertannal végzett tudományos munkájának legfontosabb megállapításaival [13].

\section{ANYAG ÉS MÓDSZER -} Materials AND MethodS

\subsection{Az érték alapú életstílus elemzés háttere - Background of Value-based Lifestyle Segmentation}

A Natural Marketing Institute (NMI) szegmentációs modelljétől [10] eltérően értékorientált életstílus elemzés segítségével határoztuk meg a magyarországi LOHAS fogyasztói csoport nagyságát. A vizsgálat során használt állításlistát Lehota, Horváth és Rácz (2013) dolgozta ki dokumentumelemzés módszerének segítségével [8]. Ennek során nyolc online keresőfelülettel rendelkező női magazin cikkeit elemezték, melyekben a szakirodalomban körvonalazott LOHAS életstílus jellemzőkkel foglalkoztak. A cikkeket az alábbi öt kategória alapján értékelték: egészségtudatosság, környezettudatosság, etikus értékek, autentikus értékek és individualizmus $[9 ; 13]$. Az irodalmi áttekintés is rávilágított arra, hogy ezek az értékkategóriák jellemzik legkarakteresebben a LOHAS életstílust. A tartalomelemzés eredményei alapján készítették el azt az 50 tényezőt tartalmazó állításlistát, amelyekből a késóbbiekben csak 25 került elemzésre, számunkra ez a lista képezte a kiinduló pontot. Az állításlista ilyen mértékű csökkentését a faktoranalízis tette szükségessé. Az 50 állításból - a végső soron - elemzésbe bevont 25 változó segítségével sikerült elérni egy, a faktorelemzés kritériumait kielégítő struktúrát.

\subsection{Mintavétel - Sampling}

A kutatás célkitüzéseinek megvalósítására egy 1000 fős országos reprezentatív kérdőíves megkérdezést indítottunk 2013 szeptemberében Magyarországon. A mintavétel során az egyes régiók esetében eleve biztosítottuk a reprezentativitást, így annak szerkezete a KSH által előzetesen megállapított kvótának teljes mértékben megfelelt (kvótás mintavétel).

Az egyes régiókban a települések kiválasztása sorsolással (egyszerü véletlen mintavétel) történt. A kijelölt településeken az ún. véletlen séta (random walking) elvét alkalmaztuk, amely teljes véletlenszerüséget biztosított a megfelelő válaszadók kiválasztásához. Második lépésben a felkeresett háztartás lakói közül az ún. születésnapi kulcs alkalmazásával választottuk ki az interjúra megfelelő személyt. A módszer lényege, hogy a megfelelő korú személyek közül (18 éves vagy annál idősebb) azt a fogyasztót kell kiválasztani, akinek a születési dátuma (születésnapja) a legközelebb esik a megkérdezés napjához.

Mivel a véletlen mintavétel nem biztosította a minta és az alapsokaság közötti reprezentativitást (az országos arányokhoz képest több volt a nő és az idősebb válaszadó), ezért a mintát korrigáltuk a többdimenziós súlyfaktorokkal nem és kor szerint. A korrekciót követően a minta négy tényező (régió, településtípus, nem, kor) alapján tükrözi az alapsokaság összetételét. 


\subsection{Kérdőív - Questionnaire}

Az értékorientált életstílus kutatás során 25 életstílus-állítást fogalmaztunk meg. A 25 állítás 5 tényező mentén került kialakításra [13], amelyek a következők voltak: környezettudatos értékek (1-3. állítás), egészségtudatos értékek (4-9. értékek), etikus értékek (10-14. állítás), autentikus értékek (15-18. állítás), individualista értékek (19-25. állítás). Ez után arra kértük a válaszadókat, hogy egy öttagú intervallumskála segítségével (1=egyál- talán nem ért egyet, $5=$ teljes mértékben egyetért) értékeljék az egyes állításokat.

A kérdőív végére kerültek a szocio-demográfiai háttérváltozók, így a nem, az életkor, az iskolai végzettség, az elsődleges élelmiszer-beszerző személye, a szubjektív jövedelemérzet (az átlagoshoz képest hogyan ítéli meg saját jövedelmét?), valamint a településtípus. A minta szocio-demográfiai háttérváltozók szerinti megoszlását az $1_{a}$ és $1_{b}$ táblázat szemlélteti.

\begin{tabular}{|c|c|c|}
\hline \multirow[t]{2}{*}{ Megnevezés (Criterion) } & \multicolumn{2}{|c|}{$\begin{array}{c}\text { A minta megoszlása } \\
\text { (Division of the Sample) }\end{array}$} \\
\hline & $\mathbf{N}$ & $\%$ \\
\hline \multicolumn{3}{|l|}{ Összes megkérdezett szerint (Total number of respondent) } \\
\hline Összesen (Total) & 1000 & 100,0 \\
\hline \multicolumn{3}{|l|}{ Nemek szerint (Gender) } \\
\hline Férfi (Men) & 490 & 49,0 \\
\hline Nő (Women) & 510 & 51,0 \\
\hline \multicolumn{3}{|l|}{ Kor szerint (Age) } \\
\hline 18-29 éves (18-29 years) & 258 & 25,8 \\
\hline 30-39 éves (30-39 years) & 181 & 18,1 \\
\hline 40-49 éves ( $40-49$ years) & 207 & 20,7 \\
\hline $50-59$ éves ( $50-59$ years) & 162 & 16,2 \\
\hline 60 év felett (Over 60 years) & 192 & 19,2 \\
\hline \multicolumn{3}{|l|}{ Iskolai végzettség szerint (Education) } \\
\hline Maximum 8 általánost végzett (Elementary school) & 116 & 11,6 \\
\hline Szakmunkásképzőt végzett (Vocational school) & 318 & 31,8 \\
\hline Érettségizett (High school degree) & 395 & 39,5 \\
\hline Felsőfokú végzettségű (University degree) & 171 & 17,1 \\
\hline \multicolumn{3}{|l|}{ Szubjektív jövedelemérzet szerint (Subjective income) } \\
\hline Rendszeres napi megélhetési gondjai vannak (Have regular financial problems) & 21 & 2,1 \\
\hline $\begin{array}{l}\text { Néha arra sem nagyon elég, hogy megéljenek belöle (Sometimes cannot make } \\
\text { ends meet) }\end{array}$ & 135 & 13,5 \\
\hline $\begin{array}{l}\text { Éppen elegendő, hogy megéljenek belőle, de félretenni már nem tudnak (Just en- } \\
\text { ough to live on, but cannot save) }\end{array}$ & 503 & 50,3 \\
\hline Megélnek belóle, de keveset tudnak félretenni (Can live on it, but can save little) & 283 & 28,3 \\
\hline $\begin{array}{l}\text { Nagyon jól megélnek belóle és félre is tudnak tenni (Can live on it very well and } \\
\text { can also save) }\end{array}$ & 36 & 3,6 \\
\hline Nem válaszol (No answer) & 22 & 2,2 \\
\hline
\end{tabular}




\begin{tabular}{|c|c|c|}
\hline \multirow[t]{2}{*}{ Megnevezés (Criterion) } & \multicolumn{2}{|c|}{$\begin{array}{c}\text { A minta megoszlása } \\
\text { (Division of the Sample) }\end{array}$} \\
\hline & $\mathbf{N}$ & $\%$ \\
\hline \multicolumn{3}{|l|}{ Településtípus szerint (Settlement) } \\
\hline Főváros (Capital city) & 188 & 18,8 \\
\hline Megyei jogú város (County town) & 221 & 22,1 \\
\hline 10 ezer fónél nagyobb város (Town with more than 10 ooo residents) & 179 & 17,9 \\
\hline 2 és 10 ezer fő közötti település (Town with between 2 ooo-10 ooo residents) & 236 & 23,6 \\
\hline 2 ezer fónél kisebb település (Settlement with less than 2 ooo residents) & 176 & 17,6 \\
\hline
\end{tabular}

\subsection{Adatelemzés - Statistical Analysis}

A kérdőívek feldolgozása a célnak megfelelő matematikai-statisztikai program segítségével (SPSS 19.0) történt. A hiányzó értékeket az adatbázisban minden esetben a mintaátlaggal helyettesítettük. $\mathrm{Az}$ adatfeldolgozás keretében a leíró statisztikák mellett, két- és többváltozós összefüggés vizsgálatokat végeztünk, melyek során kereszttábla-, variancia-, faktor- és klaszterelemzést alkalmaztunk. Az egymásra épített faktor- és klaszteranalízis alkalmas különböző szegmensek meghatározására [2; $3 ; 9 ; 15]$.

A kutatás céljának elérése érdekében első lépésként faktorelemzés segítségével elemeztük a fenntartható értékrend hazai megjelenését. A tényezőcsoportok megbízhatósági vizsgálatához Cronbach's Alfa értékeket számítottunk, mely az 5 tényező mentén kialakított dimenziók belső konzisztenciáját mutatja. A faktorelemzést a faktorértékek eloszlásának ferdeségvizsgálatával egészítettük ki [18].

A faktorelemzést követően elvégeztük a magyar fogyasztók értékrend alapú életstílus szegmentációját klaszteranalízis segítségével. A minta nagy elemszámára való tekintettel [14] a nem hierarchikus eljárást választottuk, ezen belül pedig a k-means módszert alkalmaztuk. A klaszterelemzésnél figyelembe vettük az F értékeket. Segítségükkel meghatároztuk, hogy mely változók mentén sikerült homogénebb csoportokat kialakítani, mely változók klaszterképző ereje a legnagyobb. Az egyes klaszterek szocio-demográfiai ismérvek szerinti jellemzését kereszttábla-elemzés, életstílus szerinti jellemzését pedig varianciaelemzés segítségével végeztük. A szignifikáns varianciaanalízis-eredmény mindössze azt jelenti, hogy a kategóriák átlagai kö- zött általában van különbség, azonban nem tudjuk, hogy pontosan mely átlagok között van eltérés. Ennek vizsgálatára post-hoc tesztet végeztünk.

A LOHAS értékek iránt legelkötelezettebb fogyasztói csoport nagyságának becslését szintén k-means eljárással hajtottuk végre az előzőekben leírtakkal megegyezően.

\section{EREDMÉNYEK ÉS ÉRTÉKELÉSÜK - RESULTS AND DisCUSSION}

Az eredmények alapján mindenekelőtt megállapítható ( $2_{a}$ és $2_{b}$ táblázat), hogy a magyar lakosság az etikus értékeket, azon belül az ún. kompetencia értékeket (amit saját maga tudna tenni a közösségért) tartja önmagára nézve a legkevésbé igaznak. Ide tartozik az adományozói magatartás, az önkéntes munka végzése, valamint az állatkísérletektől mentes termékek vásárlása; ezen állítások esetében kifejezetten alacsony a mintaátlag, nagy a szórás és a relatív szórás (relatív szórás: 49,79-67,76), ami azt jelzi, hogy a válaszok nagyon heterogének, vagyis az átlag már nem jellemzi jól az adatsort. A másik differenciáló tényezőcsoport az individualista értékek mentén határozható meg. Az átlagok ebben az esetben magasabbak, viszont itt is nagy a szórás és a relatív szórás értéke (relatív szórás: 38,54-50,70). Ezzel szemben a környezet- és egészségtudatos, továbbá az autentikus értékeket, és a vállalati etikát kifejezetten fontosnak tartják.

Az eredmények jelzik azt is, hogy a magyar fogyasztók preferenciarendszerében az etikus és az individualista értékek mentén húzódnak a legélesebb határvonalak. Velük szemben lényegesen homogénebb a megítélése a környezet- és az egészségtudatos-, valamint az autentikus értékeknek. 
A fenntartható értékrend szerinti életstílus-állításokkal történó egyetértés

TABLE 2 fontosabb statisztikai mutatói értékcsoportok szerint

(Major Statistical Indicators of Agreement with Statements of Sustainable Value-based Lifestyle According to Value Dimensions)

\begin{tabular}{|c|c|c|c|}
\hline \multirow[b]{2}{*}{$\begin{array}{c}\text { Állítások } \\
\text { (Statements) }\end{array}$} & \multicolumn{3}{|c|}{$\begin{array}{l}\text { Statisztikai mutató } \\
\text { (Statistical Indicator) }\end{array}$} \\
\hline & $\begin{array}{l}\text { Átlag } \\
\text { (Mean) }\end{array}$ & $\begin{array}{l}\text { Szórás } \\
\text { (Standard } \\
\text { Deviation) }\end{array}$ & $\begin{array}{c}\text { Relatív } \\
\text { szórás, \% } \\
\text { (Coefficient } \\
\text { of } \\
\text { Variation) }\end{array}$ \\
\hline \multicolumn{4}{|c|}{ Környezettudatos értékek (Environmental consciousness) } \\
\hline $\begin{array}{l}\text { Fontos, hogy a megvásárolt termék csomagolása újrahasznosítható le- } \\
\text { gyen. }\end{array}$ & 3,95 & 1,136 & 28,76 \\
\hline $\begin{array}{l}\text { Az energiatakarékos háztartási berendezések hozzájárulnak a fenntart- } \\
\text { ható fejlődéshez. }\end{array}$ & 4,34 & 0,821 & 18,92 \\
\hline $\begin{array}{l}\text { Szükséges, hogy a gyerekek környezettudatos nevelésben részesülje- } \\
\text { nek. }\end{array}$ & 4,60 & 0,673 & 14,63 \\
\hline \multicolumn{4}{|c|}{ Egészségtudatos értékek (Health consciousness) } \\
\hline $\begin{array}{l}\text { Előnyben részesítem az olyan élelmiszereket, amelyek hozzájárulnak } \\
\text { egészségem megőrzéséhez. }\end{array}$ & 4,18 & 0,938 & 22,44 \\
\hline $\begin{array}{l}\text { Napi étkezésem tervezésekor figyelek arra, hogy megfelelő mennyiség- } \\
\text { ben hozzájussak a szervezetem számára nélkülözhetetlen tápanyagok- } \\
\text { hoz. }\end{array}$ & 3,70 & 1,115 & 30,14 \\
\hline Az egészség megőrzéséhez nélkülözhetetlen a sport. & 4,11 & 1,008 & 24,52 \\
\hline $\begin{array}{l}\text { Rendszerint szezonális termékeket (pl. dinnye augusztusban) vásáro- } \\
\text { lok. }\end{array}$ & 4,21 & 0,979 & 23,25 \\
\hline $\begin{array}{l}\text { Az élelmiszerekben megtalálható adalékanyagok károsítják az egészsé- } \\
\text { gemet. }\end{array}$ & 4,07 & 0,925 & 22,73 \\
\hline $\begin{array}{l}\text { Az egészséges táplálkozás szempontjából fontos, hogy az ember tisztá- } \\
\text { ban legyen az élelmiszer összetevők (pl. vitaminok, ásványi anyagok, } \\
\text { élelmi rostok) élettani hatásaival. }\end{array}$ & 4,15 & 0,931 & 22,43 \\
\hline \multicolumn{4}{|l|}{ Etikus értékek (Ethical values) } \\
\hline Rendszerint adományokkal támogatom a civil szervezetek munkáját. & 2,27 & 1,371 & 60,40 \\
\hline Évente végzek önkéntes munkát. & 2,05 & 1,389 & 67,76 \\
\hline $\begin{array}{l}\text { Kedvezőbben ítélem meg azt a vállalatot, amelyik jótékonysági akció- } \\
\text { kat támogat. }\end{array}$ & 3,58 & 1,266 & 35,36 \\
\hline $\begin{array}{l}\text { Kedvezőbben ítélem meg azt a vállalatot, amelyik megfelelő munkakö- } \\
\text { rülményeket biztosít alkalmazottai számára. }\end{array}$ & 4,04 & 1,160 & 28,71 \\
\hline Kizárólag állatkísérletektől mentes termékeket vásárolok. & 2,80 & 1,394 & 49,79 \\
\hline \multicolumn{4}{|c|}{ Autentikus értékek (Authentic values) } \\
\hline $\begin{array}{l}\text { Ha a helyi piacokon vásárolok élelmiszert, akkor azzal a magyar terme- } \\
\text { lőket támogatom. }\end{array}$ & 4,09 & 1,038 & 25,38 \\
\hline Fontos számomra a hagyományok tisztelete. & 4,06 & 0,969 & 23,87 \\
\hline $\begin{array}{l}\text { Magyar termékek vásárlásával hozzájárulok az ország gazdasági fejlő- } \\
\text { déséhez. }\end{array}$ & 4,16 & 0,979 & 23,53 \\
\hline $\begin{array}{l}\text { A termékeken szereplő védjegyek (pl. magyar termék) csökkentik a bi- } \\
\text { zonytalanságot a vásárlás során. }\end{array}$ & 3,87 & 1,051 & 27,16 \\
\hline
\end{tabular}

${ }^{1}$ Minél nagyobb a relatív szórás értéke, annál heterogénebb az adott állításra adott válasz. (The bigger the value of the coefficient of variation is, the more heterogeneous the answer given to the statement is.) 
2

A fenntartható értékrend szerinti életstílus-állításokkal történő egyetértés

TABLE $2_{b}$ fontosabb statisztikai mutatói értékcsoportok szerint

(Major Statistical Indicators of Agreement with Statements of Sustainable Value-based Lifestyle According to Value Dimensions)

\begin{tabular}{|c|c|c|c|}
\hline \multirow[b]{2}{*}{$\begin{array}{c}\text { Állítások } \\
\text { (Statements) }\end{array}$} & \multicolumn{3}{|c|}{$\begin{array}{c}\text { Statisztikai mutató } \\
\text { (Statistical Indicator) }\end{array}$} \\
\hline & $\begin{array}{l}\text { Átlag } \\
\text { (Mean) }\end{array}$ & $\begin{array}{c}\text { Szórás } \\
\text { (Standard } \\
\text { Deviation) }\end{array}$ & $\begin{array}{c}\text { Relatív } \\
\text { Szórás, \%1 } \\
\text { (Coefficient } \\
\text { of } \\
\text { Variation) }\end{array}$ \\
\hline \multicolumn{4}{|c|}{ Individualista értékek (Individualism) } \\
\hline Fontos számomra a karrier. & 3,17 & 1,341 & 42,30 \\
\hline A márkás termékeket részesítem előnyben. & 2,84 & 1,228 & 43,24 \\
\hline Az egyedi kivitelezésű termékeket kedvelem. & 2,88 & 1,228 & 42,64 \\
\hline Fontos számomra a stílus. & 3,22 & 1,263 & 39,22 \\
\hline A legújabb divat szerint alakítom életvitelemet. & 2,43 & 1,232 & 50,70 \\
\hline Olyan termékeket vásárolok, amelyek tükrözik személyiségemet. & 3,05 & 1,236 & 40,52 \\
\hline A magas minőségű termékeket kedvelem. & 3,15 & 1,214 & 38,54 \\
\hline
\end{tabular}

\subsection{A faktoranalízis eredményei - Results of} Factor Analysis

A fenntartható értékrend hazai megjelenését faktorelemzés segítségével vizsgáltuk. Ennek során, a kérdőíven szereplő 25 fenntartható értékrendre vonatkozó állítás [13] segítségével olyan értékeket azonosítottunk, amelyek a magyar fogyasztókat kisebb-nagyobb mértékben jellemzik. A 3. táblázat eredményei azt jelzik, hogy a magyar fogyasztók értékrendjében a fenntarthatóság irányába mutató jellemzők jelen vannak, és azok hat fó csoportba (faktorba) különülnek el.

Az első faktorba tömörülnek az individualista értékek (magyarázott variancia: 18,802\%). Ide olyan tényezők kerültek, mint a divat, a márka, a stílus, vagy az egyedi termékek kedvelése, a karrier, a minőség és a személyiség értékként történő kezelése. A magas faktorsúlyok arra utalnak, hogy az értékdimenzió nagy mértékben alakítja a magyar fogyasztók értékrendjét, és élesen elkülönül a többitől. A faktor ferdeségét (Skewness mutató) vizsgálva megállapítható, hogy az eloszlás balra ferde (Skewness = -0,199), azaz a magyar fogyasztók önmagukra nézve inkább igaznak vélik az individualizmust.

A második faktor jeleníti meg az autentikus értékeket, ahol a magyarázott variancia $11,653 \%$. Fontos szerepet játszik a nemzeti termékek szeretete, a helyi (lokális) értékek megléte, a hagyomá- nyok tisztelete. A viszonylag magas faktorsúlyok azt mutatják, hogy az autentikus értékek jelentősen elkülönülnek a többi értéktényezőtől. Közülük is kiemelkedő súllyal szerepel a magyar termékek vásárlása, illetve a hazai termelők támogatása, másképpen a nemzeti elkötelezettség. A faktor jelentősen balra ferde (Skewness= -0,991), azaz a magyar fogyasztókra erősen jellemző az autentikus értékek elfogadása.

A harmadik faktor a környezettudatos értékrendhez tartozó tényezőket gyújti egy csokorba (magyarázott variancia: 10,538\%). Ez a dimenzió erősen jelen van a hazai lakosság értékrendjében, főként a környezettudatos nevelés és az újrahasznosíthatóság területén. Fontos eleme ennek a gondolkodásmódnak az energiatakarékosság is. A faktor balra ferdesége itt is kifejezett (Skewness= -0,735), vagyis a hazai lakosság önmagára nézve igaznak véli a dimenziót.

A negyedik faktorba olyan etikus tényezők kerültek, amelyek a fogyasztók saját kompetenciájaként értelmezhetók (magyarázott variancia: 8,341\%). Ilyen jellemzók a civil szervezetek tevékenységének támogatása adományokkal, illetve az önkéntes munka végzése. Lényegesen kisebb súllyal, de megjelenik az állatkísérletektől mentes termékek preferenciája is. Az eloszlás ferdesége (Skewness $=0,627$ ) arra utal, hogy ezt az értéket a fogyasztók nem igazán tartják önmagukra nézve jellemzőnek. 
Az ötödik faktor az egészségtudatossághoz tartozó értékeket jeleníti meg (magyarázott variancia: 7,272\%). A viszonylag alacsony faktorsúlyok arra utalnak, hogy ez a dimenzió - a többihez képest kisebb szerepet játszik a hazai lakosság értékítéletében. Ennek ellenére a faktor inkább balra ferde (Skewness $=-0,828$ ), vagyis ez a magatartás pozitív előjellel jelenik meg a lakossági gondolkodásmódban.

Az utolsó, vagyis a hatodik faktor két olyan etikus értéket jelenít meg, amely a vállalati magatartás megítélésére vonatkozik (magyarázott variancia: 5,993\%). Ide sorolható a kedvező munkakörülmények biztosítása, illetve a vállalat jótékonysági akciókat támogató magatartása. Az elóbbi esetében a faktorsúly nagyon magas, vagyis a munkakörülmények optimalizálása fontos kritérium a lakosság értékrendszerében. Az eloszlás balra ferdesége (Skewness=-0,727) alapján ezt az értéket is igaznak vélik önmagukra nézve a fogyasztók.

Az eredmények összefoglalásaként kijelenthető, hogy a hazai fogyasztók értékrendjében elkülönülnek azok a dimenziók, amelyek a fenntartható fogyasztás irányába mutatnak. Ebben a hibrid életstílusban egyszerre jelenik meg az egészség- és környezettudatosság, valamint az etikus és autentikus értékek elfogadása (társadalmi, közösségi értékek). Mindemellett meghatározó szerepet játszik az egyéni értékrend (individualizmus) is, amely nagy súllyal van jelen a magyar lakosság gondolkodásmódjában. Az etikus (kompetencia) értékek (egyéni kezdeményezés) a legkevésbé fontosak a magyar fogyasztók számára, miközben ugyanezt a vállalatoktól szigorúan elvárják.

A ferdeségvizsgálat alapján az etikus kompetenciaértékek azok, amelyeket a legkevésbé tartanak igaznak önmagukra nézve a fogyasztók. Velük szemben az autentikus értékek, az egészség- és környezettudatosság, valamint az etikus vállalati magatartás kiemelten fontos a hazai lakosság számára. A vázolt két kategória között helyezkedik el az individualizmus, amelyet a 2., a 3., az 5. és a 6. faktorhoz képest kevésbé tartanak fontosnak magukra nézve a magyarok, miközben a 4. faktorhoz képest inkább jellemzi őket.

Az értékstruktúra belső sajátosságairól árnyaltabb képet kapunk akkor, ha az eloszlások ferdeségét háttérváltozói (szocio-demográfiai) csoportok szerint elemezzük (4. táblázat).

A kérdés ebben az esetben az, hogy tapasztal- ható-e eltérés a fogyasztók értékhierarchiájában az egyes dimenziók (értékcsoportok) megítélésében. Külön hangsúlyozandó, hogy a ferdeség vizsgálata nem alkalmas piaci szegmentációra, de iránymutató jelleggel jobban felvázolható a LOHAS fogyasztó hibrid életstílusát jellemző értékstruktúra [13]. A kapott eredmények szerint az individualista értékrend inkább jellemző a fiatalokra, a nőtlenekre (hajadonokra), a magasabb iskolai végzettségü, magas jövedelmú, döntően Budapesten élő személyekre. Az autentikus megközelítést inkább a férfiak, kor szerint az idősebbek és az egyedül élők, ugyanakkor magasabb társadalmi státuszúak képviselik leginkább. A környezettudatosság eszméje szorosabban kapcsolódik a kisebb településekhez, illetve az érettségizett és háztartásbeli személyekhez. $\mathrm{Az}$ etikus kompetenciaértékek leginkább a 2000 lakosnál kevesebbet számláló településen élőkre jellemző, ugyanakkor végzettség szerint egyértelmúen a diplomával rendelkezők érzik szükségét az önkéntes munkának és az adományozói magatartásnak. Az egészségtudatosság is erősen kötődik a magasabb iskolai végzettséghez, egyértelmüen élen járnak a nők és a nagyobb települések lakói. Az etikus vállalati magatartás iránti elköteleződés legerőteljesebben a kiemelkedő jövedelmi státuszhoz áll legközelebb, ami jelzi a csoport eröteljes kötödését a vállalati szektorhoz és a CSR tevékenységhez. Ha a hat értékfaktor közötti öszszekötő kapcsolatot keressük, akkor egyértelmüen kirajzolódik, hogy az iskolai végzettség szinte valamennyi értékdimenzióban megjelenik. Legalább ennyire fajsúlyos a család jövedelmi pozíciója is, a jobb anyagi körülmények „hajlamosítanak” a LOHAS életstílus követésére. A harmadik összekötő kapocs a foglalkozás: az aktív szellemi tevékenységet folytatók több értéket is jobban magukénak éreznek, mint a többi foglalkozási csoport.

A fenntartható értékrend alapú életstílus szegmentáció elvégzése előtt szükségesnek véltük az alkalmazott állításlista validálását (5. táblázat).

$\mathrm{Az}$ eredmények igazolják, hogy az állításlista alkalmas a vizsgált dimenziók jellemzésére. Ugyanakkor egy esetben, az etikus kompetenciaértékeknél „Az állatkísérletektől mentes termékek vásárlása" állítás elhagyása jelentős mértékben javítaná a változók belső konzisztenciáját, ugyanakkor ennek kiiktatását az értékdimenzió alacsony elemszáma miatt nem tartottuk szakmailag indokoltnak. 
A fenntartható értékrend szerinti életstílus elemzése során kapott faktorok (Factors Formed Based on Sustainable Value-based Lifestyle)

\begin{tabular}{|c|c|c|c|}
\hline Állítások (Statements) & 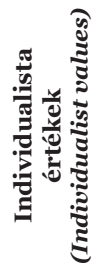 & 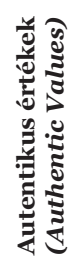 & 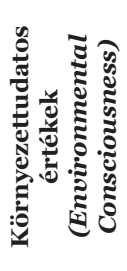 \\
\hline 1. A márkás termékeket részesítem előnyben. & 0,826 & & \\
\hline 2. Olyan termékeket vásárolok, amelyek tükrözik személyiségemet. & 0,821 & & \\
\hline 3. Az egyedi kivitelezésű termékeket kedvelem. & 0,818 & & \\
\hline 4. Fontos számomra a stílus. & 0,814 & & \\
\hline 5. A legújabb divat szerint alakítom életvitelemet. & 0,801 & & \\
\hline 6. A magas minőségü termékeket kedvelem. & 0,781 & & \\
\hline 7. Fontos számomra a karrier. & 0,668 & & \\
\hline 8. A magyar termékek vásárlásával hozzájárulok az ország gazdasági fejlődéséhez. & & 0,797 & \\
\hline 9. Ha a helyi piacokon vásárolok élelmiszert, akkor azzal a magyar termelóket támogatom. & & 0,749 & \\
\hline 10. Fontos számomra a hagyományok tisztelete. & & 0,747 & \\
\hline $\begin{array}{l}\text { 11. A termékeken szereplő védjegyek (pl. magyar termék) csökkentik a bizonytalanságot a vásárlás } \\
\text { során. }\end{array}$ & & 0,689 & \\
\hline 12. Szükséges, hogy a gyerekek környezettudatos nevelésben részesüljenek. & & & 0,763 \\
\hline 13. Fontos, hogy a megvásárolt termék csomagolása újrahasznosítható legyen. & & & 0,761 \\
\hline 14. Az energiatakarékos háztartási berendezések hozzájárulnak a fenntartható fejlődéshez. & & & 0,700 \\
\hline
\end{tabular}

\begin{tabular}{|c|c|c|c|}
\hline Állítások (Statements) & 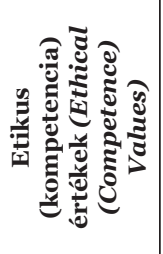 & 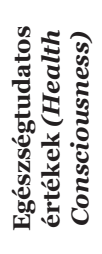 & 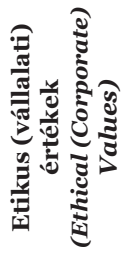 \\
\hline 15. Rendszerint adományokkal támogatom a civil szervezetek munkáját. & 0,881 & & \\
\hline 16. Évente végzek önkéntes munkát. & 0,870 & & \\
\hline 17. Kizárólag állatkísérletektől mentes termékeket vásárolok. & 0,358 & & \\
\hline 18. Rendszerint szezonális termékeket (pl. dinnye augusztusban) vásárolok. & & 0,790 & \\
\hline $\begin{array}{l}\text { 19. Napi étkezésem tervezésekor figyelek arra, hogy megfelelő mennyiségben hozzájussak a } \\
\text { szervezetem számára nélkülözhetetlen tápanyagokhoz. }\end{array}$ & & 0,595 & \\
\hline 20. Az egészség megőrzéséhez nélkülözhetetlen a sport. & & 0,465 & \\
\hline $\begin{array}{l}\text { 21. Elónyben részesítem az olyan élelmiszereket, amelyek hozzájárulnak egészségem meg- } \\
\text { őrzéséhez. }\end{array}$ & & 0,462 & \\
\hline 22. Az élelmiszerekben megtalálható adalékanyagok károsítják az egészségemet. & & 0,395 & \\
\hline $\begin{array}{l}\text { 23. Az egészséges táplálkozás szempontjából fontos, hogy az ember tisztában legyen az élel- } \\
\text { miszer összetevők (pl. vitaminok, ásványi anyagok, élelmi rostok) élettani hatásaival. }\end{array}$ & & 0,308 & \\
\hline $\begin{array}{l}\text { 24. Kedvezóbben ítélem meg azt a vállalatot, amelyik megfelelő munkakörülményeket biz- } \\
\text { tosít alkalmazottai számára. }\end{array}$ & & & 0,797 \\
\hline 25. Kedvezóbben ítélem meg azt a vállalatot, amelyik jótékonysági akciókat támogat. & & & 0,606 \\
\hline
\end{tabular}

Extraction Method: Principal Component Analysis; Rotation Method: Varimax rotation; Rotation converged in 6 iterations; KMO=0,878; Bartlett: (Approx. Chi Sq.) 10655,000; (Sig.) 0;000; Communalities: 0,261-0,810; Total Variance Explained: 62,601; N=1000 


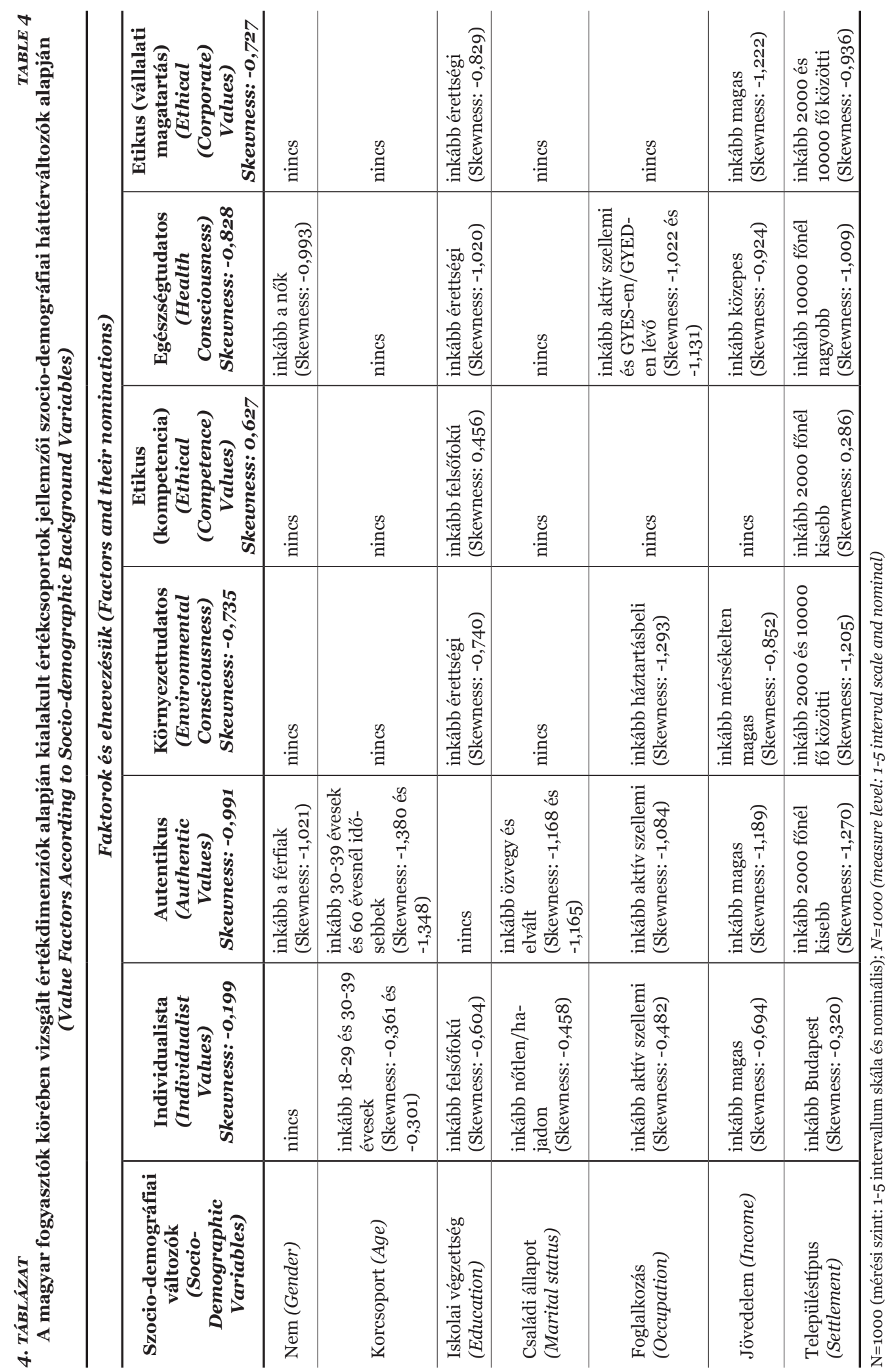




\section{(Validation of the List of Statements Describing the LOHAS Consumer's Lifestyle)}

\begin{tabular}{|c|c|c|}
\hline $\begin{array}{l}\text { Értékdimenzió } \\
\text { (Value Dimension) }\end{array}$ & Cronbach's Alfa & $\begin{array}{c}\text { Cronbach's Alfa javulása elemek } \\
\text { törlésével } \\
\text { (Cronbach's Alfa Improvement } \\
\text { Deleting Elements) }\end{array}$ \\
\hline $\begin{array}{l}\text { Környezettudatos ( } 3 \text { elem) } \\
\text { (Environmental consciousness) } \\
\text { (3 elements) }\end{array}$ & 0,730 & $\begin{array}{l}\text { nem jelentős (o,595-0,701) } \\
\text { (not significant) }\end{array}$ \\
\hline $\begin{array}{l}\text { Egészségtudatos ( } 6 \text { elem) } \\
\text { (Health consciousness) (6 elements) }\end{array}$ & 0,723 & $\begin{array}{l}\text { nem jelentős (o,645-0,723) } \\
\text { (not significant) }\end{array}$ \\
\hline $\begin{array}{l}\text { Etikus (kompetencia) ( } 3 \text { elem) } \\
\text { (Ethical competence) (3 elements) }\end{array}$ & 0,643 & $\begin{array}{l}\text { jelentős (o,831 - Állatkísérletektől } \\
\text { mentes termékek vásárlásának } \\
\text { elhagyása) } \\
\text { (significant - giving up buying pro- } \\
\text { ducts free of animal testing) }\end{array}$ \\
\hline $\begin{array}{l}\text { Etikus (vállalati) ( } 2 \text { elem) } \\
\text { (Ethical corporate) ( } 2 \text { elements) }\end{array}$ & 0,762 & $\begin{array}{l}\text { nem jelentős }(0,618) \\
\text { (not significant) }\end{array}$ \\
\hline $\begin{array}{l}\text { Autentikus (4 elem) } \\
\text { (Authentic) (4 elements) }\end{array}$ & 0,811 & $\begin{array}{l}\text { nem jelentős (o,724-0,783) } \\
\text { (not significant) }\end{array}$ \\
\hline $\begin{array}{l}\text { Individualista ( } 7 \text { elem) } \\
\text { (Individualism) (7 elements) }\end{array}$ & 0,906 & $\begin{array}{l}\text { nem jelentős (o,886-0,908) } \\
\text { (not significant) }\end{array}$ \\
\hline
\end{tabular}

N=1000 (mérési szint: 1-5 intervallumskála); $N=1000$ (measure level: 1 -5 interval scale)

\subsection{A szegmentálás eredményei - Results of Segmentation}

A faktorelemzés igazolta, hogy a kapott faktorok alkalmasak a klaszteranalízisre, ezért a következő lépésben elvégeztük a magyar fogyasztók értékrend alapú szegmentációját k-means klaszterezési eljárás segítségével. A csoportosítási eljárás lefolytatása után, a vizsgált 25 tényező mentén, öt életstílus-csoportot tudtunk elkülöníteni. Elsőként a klaszterek szocio-demográfiai hátterét mutatjuk be (6. táblázat), majd az egyes életstílus-csoportok jellemzőit a 25 vizsgált tényező mentén (7. táblázat).

\section{$\underline{\text { Az életstílus klaszterek részletes jellemzése }}$}

A következőkben a kutatás célkitüzéseinek megfelelően az egyes klaszterek részletes jellemzésére kerül sor. Az egyes csoportok életstílus sajátosságainak ismertetése előtt célszerü felhívni a figyelmet a 7. táblázatban szereplő F értékekre, amelyek jelzik, hogy az egyes fogyasztói csoportok elsősorban az individualista és a környezettudatos értékek mentén különültek el. Az individualista értékek a faktorelemzés során is a legélesebben kirajzolódó értékcsoportot hozták létre.

\section{1. klaszter - Idősödő közömbösek}

A csoport aránya 16,4\% (164 fó) az összes megkérdezett között. A szegmensben enyhén felülreprezentáltak a férfiak $(16,7 \%)$ és dominálnak az idősebb korosztályba tartozók (40-49 évesek - 20,8\%; 50-59 évesek - 19,1\%; illetve 60 évesnél idősebbek -19,3\%). A 18-29 éves fiatalok erősen alulrepezentáltak (10,1\%). A csoportban nagy arányban jelennek meg az általános iskolát végzettek $(19,8 \%)$ és a szakmunkások (24,2\%). A diplomával rendelkezők $(10,5 \%)$ viszont - a klaszter méretéhez képest - kevesen vannak. Az átlagosnál rosszabb anyagi helyzetben élők dominanciája jellemzi a szegmentumot (rendszeresen napi megélhetési gondjai vannak - 28,6\%, néha arra se nagyon elég, hogy megéljen belőle - 26,7\%), miközben alulreprezentáltak a jobb jövedelmi helyzettel rendelkező háztartások. Jellemzően 10000 főnél nagyobb városokban $(22,3 \%)$ élnek, viszont a fóvárosban lakók aránya alulreprezentált (12,8\%).

A fenntartható életmód iránti elkötelezettségük alacsony szintű, az általunk felsorolt 25 életstílus-változót - néhány kivételtől eltekintve alulértékelik, és ebben az 5 . fogyasztói klaszterhez állnak legközelebb. Különösen nagy az eltérés a környezettudatosság és az etikus kompetencia jel- 
lemzők mentén a 2., a 3. és a 4. klaszter átlagaihoz képest (Post Hoc Test, Tukey, sig<0,05), de közel azonosan gondolkodnak e két tényezőcsoportról az 5. klaszterrel (Post Hoc Test, Tukey, sig $>0,05$ ). A teljes mintasokaság átlagához képest felülértékelik a hagyományokat, valamint a helyi piacokon történő élelmiszervásárlást, amivel a helyi gazdaságot igyekeznek támogatni. Az individualista értékeket jelentősen alulértékelik, véleményük ebben is az 5. klaszteréhez áll közel (Post Hoc Test, Tukey, sig $>0,05$ )

\section{2. klaszter - Fiatal trendkövetők}

A csoport aránya a teljes mintasokaságon belül 32,1\%, azaz 321 fó, ez a legnagyobb klaszter. A szegmentumban enyhén felülreprezentáltak a nők (33,5\%) és a fiatalok (18-29 évesek - 41,9\%; 30-39 évesek - 34,3\%), a 60 évesnél idősebbek aránya viszont alacsony (22,9\%). A szegmensben erősen felülreprezentáltak a felsőfokú végzettséggel rendelkezők (47,4\%) és az érettségizettek (38,7\%), illetve alulreprezentáltak a maximum nyolc általánost végzettek (20,7\%) és a szakmunkások (19,8\%). A csoportban dominálnak a jó jövedelmi helyzettel rendelkező háztartások (megél belőle, de keveset tud félre tenni - 46,3\%; nagyon jól megél belőle és félre is tud tenni - 44,4\%), az anyagi gondokkal küzdők részesedése elenyésző (rendszeresen napi megélhetési gondjai vannak - 4,8\%, néha arra se nagyon elég, hogy megéljen belőle - 8,9\%). Jellemzően városi lakosok alkotják a klasztert, közülük is a legtöbben a 10000 fönél nagyobb városokban (39,9\%), illetve a megyeszékhelyeken $(32,1 \%)$ élnek.

A fenntartható életstílus iránti elkötelezettségük kiemelkedő, a legtöbb állítás esetében pozitív választ adtak. Az öt értékcsoport közül magas szinten teljesítenek az individualista értékdimenzió mentén, itt valamennyi tényezőnél az első helyen állnak (Post Hoc Test, Tukey, sig<0,05). Kifejezetten fontos számukra az egészség, tudatosan táplálkoznak, viszonylag rendszeresen sportolnak, a többi csoporthoz képest e tényezőket felülértékelik (Post Hoc Test, Tukey, sig<0,05). Az etikus kompetencia értékeket a 4. klaszterhez képest alulértékelik (Post Hoc Test, Tukey, sig<0,05), az etikus vállalati magatartás megítélése pedig azonos a 3. és a 4. klaszterével. Az autentikus értékek megjelennek ugyan életstílusukban, de ezek megítélése nem tér el jelentősen a 4. klaszterétől (Post Hoc Test, Tukey, sig $>0,05$ ).

\section{3. klaszter - Fiatal környezettudatosak}

Mérete alapján a harmadik legnagyobb klaszter (18,6\%, 186 fó) az öt közül. Nemek szerint a férfiak dominálnak (21,0\%), a korcsoportok közül felülreprezentáltak a $18-29$ (23,6\%), illetve a 30-39 évesek (23,8\%). Az őket követő korosztályok súlya fokozatosan csökken (40-49 évesek - 16,9\%; 50-59 évesek - 14,8\%; 60 évesnél idősebbek - 12,0\%). A szegmensben enyhén felülreprezentáltak az érettségizett és a diplomás személyek (19,2\%, illetve 20,5\%), de kisebb mértékben, mint az előző klaszterben. Jövedelem szempontjából a csoport kétpólusú: egyik oldalról dominálnak az átlagosnál valamivel rosszabb anyagi helyzetben lévők (néha arra se nagyon elég, hogy megéljen belóle - 23,0\%), a másik oldalról viszont a legjobb módúak (nagyon jól megél belőle és félre is tud tenni - 22,2\%). Lakóhely szerint is megjelenik ez a kettősség: felülreprezentáltak a fővárosiak (20,7\%), illetve a megyeszékhelyen élők (21,7\%), miközben kiemelkedő az aránya a 2000 főnél kisebb települések lakóinak.

Ha nem is szignifikáns az eltérés, de mégis ez a szegmens értékeli leginkább az újrahasznosítható csomagolást a termékeknél, illetve ők értenek egyet legnagyobb arányban azzal, hogy a gyerekeknek környezettudatos nevelésben kell részesülniük. A csoportra kevésbé jellemző az egészségtudatosság; a 2. és a 4. klaszterhez képest szignifikánsan alulértékelik az ide sorolható állításokat (Post Hoc Test, Tukey, sig<0,05). Az individualista értékek megítélése elmarad ugyan a 2. klaszterétől (Post Hoc Test, Tukey, sig<0,05), de a legtöbb jellemző esetében szignifikánsan pozitívabb, mint az 1. és a 4. szegmens véleménye. Álláspontjuk az individualista értékekről az 5. klaszteréhez áll legközelebb (Post Hoc Test, Tukey, sig>0,05).

\section{4. klaszter - Etikus hagyománytisztelők}

A klaszter a második legnagyobb csoportot alkotja a mintán belül (22,6\%, 226 fó). A klaszteren belül enyhén felülreprezentáltak a nők (23,9\%), kor szerint dominálnak a 40 évesnél idősebbek (40-49 évesek - 24,2\%; 50-59 évesek - 25,3\%; 60 évesnél idősebbek - 37,0\%). A szegmentum felülreprezentált a maximum nyolc általánost végzettek (30,2\%), illetve a szakmunkások (25,8\%) körében, az érettségizettek és a diplomások aránya a csoport súlyához mérten alacsony (20,8\%, illetve 15,8\%). Viszonylag kiegyensúlyozott anyagi helyzet jellemzi a klasztert, túlsúlyban vannak a valamivel az átlag alatti, illetve az átlagos jövedelemből élők (néha 
arra se nagyon elég, hogy megéljen belóle - 28,9\%; éppen elegendő, hogy megéljen belőle, de félretenni már nem tud - 24,7\%). Jellemzően kisebb településeken élnek (2000 és 10000 lakos közötti város - 29,3\%; 2000 lakos alatti község - 27,0\%), vagy a fóváros lakói $(24,5 \%)$.

A klaszter vezető pozícióban van az etikus kompetenciaértékek megítélésében, ezen a téren jobban teljesít a többi csoportnál. A szegmens tagjai szívesebben támogatnak adományokkal civil szervezeteket, gyakrabban végeznek önkéntes munkát (Post Hoc Test, Tukey, sig<0,05), mint a többiek. A 2. és a 3. klaszterrel azonos szinten értékelik a vállalatok etikus magatartását, elvárják a jótékonysági akciókat és a megfelelő munkakörülményeket (Post Hoc Test, Tukey, sig>0,05). Az 1. és az 5. klaszterhez képest környezet- és egészségtudatosságuk fokozottabb (Post Hoc Test, Tukey, sig<0,05), de az idesorolható jellemzők megítélésében véleményük nem tér el szignifikánsan a 2. és a 3. szegmenstől (Post Hoc Test, Tukey, sig>0,05). A szegmens erősen hagyománytisztelő személyekből áll, ami valószínúleg összefüggésbe hozható idősebb korukkal és etikus magatartásukkal.

\section{5. klaszter - Csalódott pesszimisták}

A klaszterbe a megkérdezettek 10,3\%-a jelenik meg, összesen 103 fó. A szegmens nemek szerinti összetétele kiegyensúlyozott, a korcsoportok között enyhén dominálnak a 18-29 évesek (12,0\%), ugyanakkor alulreprezentáltak az 50 évesnél idősebbek (50-59 évesek - 9,9\%; 60 évesnél idősebbek - 8,9\%). Jellemzően általános iskolát végzettek $(13,8 \%)$, illetve szakmunkások (12,3\%) alkotják a klasztert, a diplomával rendelkezők erősen alulreprezentáltak (5,8\%). A szegmentumban nagy arányban jelennek meg a komoly megélhetési problémákkal küzdők (33,3\%) és nagyon alacsony a félretenni tudók tábora. A csoport legnagyobb része 2 és 10 ezer fős településeken él (27,0\%).

Jellemzően valamennyi állítást alulértékelik a többi klaszterhez képest, véleményük legtöbb esetben az Idősödő közömbösek szegmenséhez áll közel. A közömbösekkel azonos módon alulértékelik a környezet- és az egészségtudatossággal összefüggő értékeket, de megítélésük az etikus kompetencia értékeket illetően is hasonló (Post Hoc Test, Tukey, sig $>0,05)$. Az etikus vállalati magatartást és az autentikus értékeket valamennyi szegmens közül a legkevésbé fogadják pozitívan (Post Hoc Test, Tukey, sig<0,05). Az individualizmussal kapcsolatos véleményük az Idősödő közömbösek és a Fiatal környezettudatosak szegmensével megegyezik (Post Hoc Test, Tukey, sig>0,05), viszont az etikus hagyománytisztelőkkel szemben - egy kivételével - valamennyi tényezőt felülértékelik (Post Hoc Test, Tukey, sig<0,05).

Az elemzés alapján összefoglalásként kijelenthető, hogy az egészségtudatos és az individualista értékek megítélésében a 2. klaszter (Fiatal trendkövetők) tagjai felülértékelnek a többi csoporthoz képest. Az autentikus kompetenciaértékek területén viszont a 4. klaszterbe (Etikus hagyománytisztelők) tartozók teljesítenek legjobban. A környezettudatos és az autentikus vállalati értékeket a 2. klaszter felülértékeli az 1. és az 5. klaszterhez képest. Ennek alapján megállapítható, hogy sikerült azonosítani egy olyan szegmentumot, amely értéktrendjét tekintve a LOHAS fogyasztót jellemző hibrid életstílust tartja önmagára nézve leginkább igaznak; a csoport a „Fiatal trendkövetők” elnevezést kapta. 
Az értékrend-alapú fogyasztói klaszterek szocio-demográfiai jellemzői, \% (Comparison of Socio-demographic Variables in Clusters, \%) (N=1OOO)

\begin{tabular}{|c|c|c|c|c|c|c|c|}
\hline \multirow{2}{*}{\multicolumn{2}{|c|}{ Változó (Variables) }} & \multicolumn{5}{|c|}{$\begin{array}{l}\text { Szocio-demográfiai jellemzók, \% } \\
\text { (Socio-demographic } \\
\text { Characteristics, \%) }\end{array}$} & \multirow[t]{2}{*}{ Szig. (Sig.) } \\
\hline & & 1. & 2. & 3. & 4. & 5. & \\
\hline \multicolumn{2}{|c|}{ Klaszter mérete (Cluster size) } & 16,4 & 32,1 & 18,6 & 22,6 & 10,3 & - \\
\hline \multirow{2}{*}{$\begin{array}{l}\text { Nem } \\
\text { (Gender) }\end{array}$} & Férfi (Men) & 16,7 & 30,6 & 21,0 & 21,2 & 10,4 & \multirow{2}{*}{0,334} \\
\hline & Nő (Women) & 16,1 & 33,5 & 16,3 & 23,9 & 10,2 & \\
\hline \multirow{5}{*}{$\begin{array}{l}\text { Korcsoport } \\
\text { (Age) }\end{array}$} & $18-29$ & 10,1 & 41,9 & 23,6 & 12,4 & 12,0 & \multirow{5}{*}{0,000} \\
\hline & $30-39$ & 14,9 & 34,3 & 23,8 & 17,7 & 9,4 & \\
\hline & $40-49$ & 20,8 & 27,5 & 16,9 & 24,2 & 10,6 & \\
\hline & $50-59$ & 19,1 & 30,9 & 14,8 & 25,3 & 9,9 & \\
\hline & $>60$ & 19,3 & 22,9 & 12,0 & 37,0 & 8,9 & \\
\hline \multirow{4}{*}{$\begin{array}{l}\text { Végzettség } \\
\text { (Education) }\end{array}$} & $\begin{array}{c}\text { Általános iskola } \\
\text { (Elementary school) }\end{array}$ & 19,8 & 20,7 & 15,5 & 30,2 & 13,8 & \multirow{4}{*}{0,000} \\
\hline & $\begin{array}{l}\text { Szakmunkásképző } \\
\text { (Vocational school) }\end{array}$ & 24,2 & 19,8 & 17,9 & 25,8 & 12,3 & \\
\hline & Érettségi (High school) & 11,6 & 38,7 & 19,2 & 20,8 & 9,6 & \\
\hline & $\begin{array}{c}\text { Felsőfokú végzettség } \\
\text { (University) }\end{array}$ & 10,5 & 47,4 & 20,5 & 15,8 & 5,8 & \\
\hline \multirow{6}{*}{$\begin{array}{l}\text { Szubjektív jövedelem } \\
\text { érzet } \\
\text { (Subjective income) }\end{array}$} & $\begin{array}{c}\text { Rendszeres megélhetési gondok } \\
\text { (Have regular financial } \\
\text { problems) }\end{array}$ & 28,6 & 4,8 & 14,3 & 19,0 & 33,3 & \multirow{6}{*}{0,000} \\
\hline & $\begin{array}{c}\text { Néha arra sem elég, hogy megél- } \\
\text { jenek belőle (Sometimes cannot } \\
\text { make ends meet) }\end{array}$ & 26,7 & 8,9 & 23,0 & 28,9 & 12,6 & \\
\hline & $\begin{array}{l}\text { Éppen elegendő, hogy megélje- } \\
\text { nek (Just enough to live on, but } \\
\text { cannot save) }\end{array}$ & 15,5 & 30,2 & 18,1 & 24,7 & 11,5 & \\
\hline & $\begin{array}{l}\text { Megélnek belőle, de keveset } \\
\text { tudnak félretenni (Can live on it, } \\
\text { but can save little) }\end{array}$ & 13,1 & 46,3 & 17,3 & 18,7 & 4,6 & \\
\hline & $\begin{array}{l}\text { Nagyon jól megélnek belőle és } \\
\text { félre is tudnak tenni (Can live on } \\
\text { it very well and can also save) }\end{array}$ & 16,7 & 44,4 & 22,2 & 8,3 & 8,3 & \\
\hline & Nincs válasz (No answer) & 4,5 & 40,9 & 18,2 & 13,6 & 22,7 & \\
\hline \multirow{5}{*}{$\begin{array}{l}\text { Településtípus } \\
\text { (Settlement) }\end{array}$} & Főváros (Capital city) & 12,8 & 30,3 & 20,7 & 24,5 & 11,7 & \multirow{5}{*}{0,000} \\
\hline & Megyeszékhely (County town) & 16,7 & 32,1 & 21,7 & 14,0 & 15,4 & \\
\hline & $\begin{array}{c}10 \text { ezer lakosnál nagyobb város } \\
\text { (Town with over } 10 \text { thousand } \\
\text { people) }\end{array}$ & 22,3 & 39,9 & 13,5 & 18,7 & 5,7 & \\
\hline & $\begin{array}{l}2 \text { és } 10 \text { ezer lakos közötti város } \\
\text { (Town with between } 2 \text { thousand } \\
\text { and } 10 \text { thousand people) }\end{array}$ & 15,0 & 29,3 & 17,1 & 29,3 & 27,0 & \\
\hline & $\begin{array}{c}\text { Község } 2 \text { ezer lakos alatt } \\
\text { (Settlement with less than } 2 \\
\text { thousand people) }\end{array}$ & 15,1 & 28,9 & 20,4 & 27,0 & 8,6 & \\
\hline
\end{tabular}




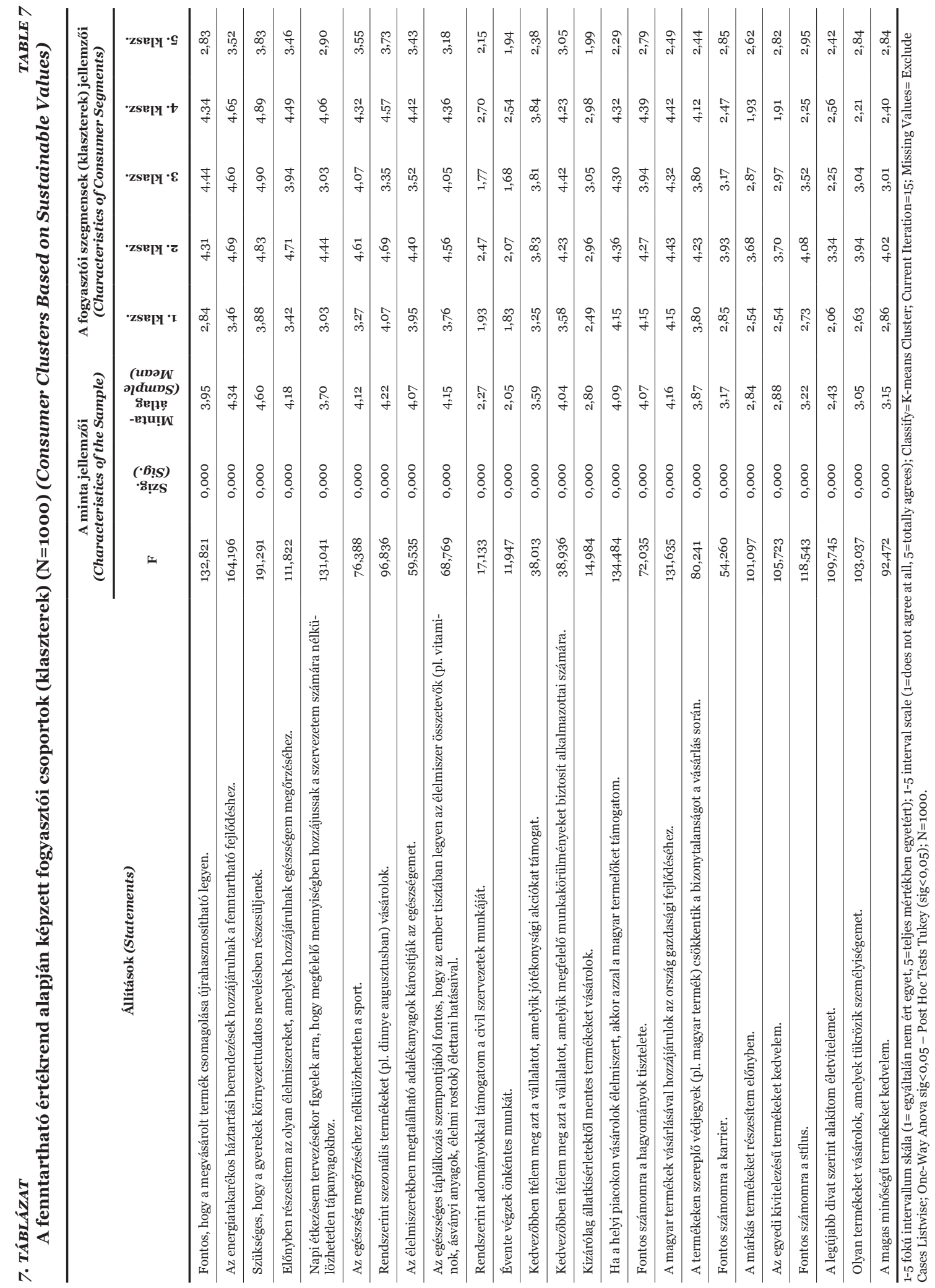




\subsection{A LOHAS fogyasztók aránya a Fiatal trendkövetők csoportján belül - \\ The Rate of LOHAS Consumers within the Group of Young Trend Followers}

Az elemzés során egyértelműen kiderült, hogy a Fiatal trendkövetők szegmense nem tekinthető teljes egészében a LOHAS értékek iránt elkötelezett fogyasztói csoportnak. Annak ellenére, hogy az egészségtudatosság, és főként az individualizmus terén a többi klasztertől élesen elkülönül, a többi értékdimenzióban nem tekinthető egyedülálló csoportnak. A leírtakat figyelembe véve célszerünek ítéltük a klaszter további részletes elemzését. Elsőként a 25 állításra adott válaszok átlagát, szórását és relatív szórását elemeztük a Fiatal trendkövetők csoportján belül ( $8_{a}$ és $8_{b}$ táblázat).

$\mathrm{Az}$ eredmények szerint a szegmens a legnagyobb homogenitást az egészségtudatosság terén mutatja, ezt az autentikus és az individualista értékek követik. Viszonylag kedvező homogenitású a környezettudatosság dimenzió is, itt azonban a relatív szórásértékek nagyobb variabilitást jeleznek. Egyértelmü, hogy a csoport az etikus kompetenciaértékek megítélése mentén mutatja a legerősebb heterogenitást, vagyis feltételezhető, hogy további szegmentációval sikeresebben elkülöníthető a magyarországi LOHAS életstílus szegmens.

A Fiatal trendkövetők szegmentálását most is a K-means eljárással hajtottuk végre, amelynek eredményeként négy klasztert kaptunk (9. táblázat).

Ha megvizsgáljuk az F-próba értékeit, akkor szembetűnő, hogy az egyes klaszterek a két etikus kompetencia érték mentén különülnek el legélesebben egymástól, vagyis e két állítás a legerősebb klaszterképző változó („Rendszerint adományokkal támogatom a civil szervezetek munkáját.”; „Évente végzek önkéntes munkát.”). Az eredmények értékelésekor célszerü megemlíteni azt is, hogy a kapott értékek a Fiatal trendkövetők csoportján belüli válaszadók véleményeinek eltérését mutatja, így a teljes mintához képest mind a négy klaszter a „Fiatal trendkövetők” sajátosságait hordozza. Az alklaszterek kis elemszámára tekintettel háttérváltozók szerint nem elemezzük az egyes csoportokat, helyette a Fiatal trendkövetők csoportjánál leírtak az irányadók.

A többi csoporthoz képest a harmadik alklaszter az, amelyik jelentősen felülértékeli az etikus kompetencia-jellemzőket (Post Hoc Test, Tukey, sig<0.05), illetve jól teljesít az individualista értékdimenzióban is. Ennek alapján megállapítható, hogy a Fiatal trendkövetők csoportján belül a harmadik alklaszter hordozza legkarakteresebben a LOHAS fogyasztókra jellemző hibrid életstílust Magyarországon. Aránya a Fiatal trendkövetők csoportján belül 27,1\%, a teljes mintán belül pedig $8,7 \%$. Az eredmények alapján összefoglalva megállapítható, hogy a fenntarthatóság iránt elkötelezett (LOHAS) fogyasztók aránya hazánkban is elérte azt a szintet, amelynek nagysága megbízható módon becsülhető.

A fenntartható értékrend szerinti életstílus-állításokkal történő egyetértés

TABLE $8_{a}$ fontosabb statisztikai mutatói a Fiatal trendkövetők szegmensében (n=321) Major Statistical Indicators of Sustainable Value-based Lifestyle in the Segment of Young Trend Followers $(n=321)$

\begin{tabular}{|c|c|c|c|}
\hline \multirow[b]{2}{*}{$\begin{array}{c}\text { Állítások } \\
\text { (Statements) }\end{array}$} & \multicolumn{3}{|c|}{$\begin{array}{l}\text { Statisztikai mutató } \\
\text { (Statistical Indicator) }\end{array}$} \\
\hline & $\begin{array}{l}\text { Átlag } \\
\text { (Mean) }\end{array}$ & $\begin{array}{c}\text { Szórás } \\
\text { (Standard } \\
\text { Deviation) }\end{array}$ & $\begin{array}{c}\text { Relatív } \\
\text { Szórás, \%1 } \\
\text { (Coefficient } \\
\text { of } \\
\text { Variation) }\end{array}$ \\
\hline \multicolumn{4}{|c|}{ Környezettudatos értékek (Environmental consciousness) } \\
\hline $\begin{array}{l}\text { Fontos, hogy a megvásárolt termék csomagolása újrahasznosítható le- } \\
\text { gyen. }\end{array}$ & 4,31 & 0,896 & 20,78 \\
\hline $\begin{array}{l}\text { Az energiatakarékos háztartási berendezések hozzájárulnak a fenntart- } \\
\text { ható fejlődéshez. }\end{array}$ & 4,69 & 0,522 & 11,13 \\
\hline $\begin{array}{l}\text { Szükséges, hogy a gyerekek környezettudatos nevelésben részesülje- } \\
\text { nek. }\end{array}$ & 4,83 & 0,396 & 8,20 \\
\hline
\end{tabular}


A fenntartható értékrend szerinti életstílus-állításokkal történő egyetértés fontosabb statisztikai mutatói a Fiatal trendkövetôk szegmensében (n=321) Major Statistical Indicators of Sustainable Value-based Lifestyle in the Segment of Young Trend Followers $(n=321)$

\begin{tabular}{|c|c|c|c|}
\hline \multirow[b]{2}{*}{$\begin{array}{c}\text { Állítások } \\
\text { (Statements) }\end{array}$} & \multicolumn{3}{|c|}{$\begin{array}{c}\text { Statisztikai mutató } \\
\text { (Statistical Indicator) }\end{array}$} \\
\hline & $\begin{array}{l}\text { Átlag } \\
\text { (Mean) }\end{array}$ & $\begin{array}{l}\text { Szórás } \\
\text { (Standard } \\
\text { Deviation) }\end{array}$ & $\begin{array}{c}\text { Relatív } \\
\text { Szórás, \%1 } \\
\text { (Coefficient } \\
\text { of } \\
\text { Variation) }\end{array}$ \\
\hline \multicolumn{4}{|c|}{ Egészségtudatos értékek (Health consciousness) } \\
\hline $\begin{array}{l}\text { Előnyben részesítem az olyan élelmiszereket, amelyek hozzájárulnak } \\
\text { egészségem megőrzéséhez. }\end{array}$ & 4,71 & 0,499 & 10,59 \\
\hline $\begin{array}{l}\text { Napi étkezésem tervezésekor figyelek arra, hogy megfelelő mennyiség- } \\
\text { ben hozzájussak a szervezetem számára nélkülözhetetlen tápanyagok- } \\
\text { hoz. }\end{array}$ & 4,44 & 0,727 & 16,37 \\
\hline Az egészség megőrzéséhez nélkülözhetetlen a sport. & 4,61 & 0,672 & 14,58 \\
\hline $\begin{array}{l}\text { Rendszerint szezonális termékeket (pl. dinnye augusztusban) vásáro- } \\
\text { lok. }\end{array}$ & 4,69 & 0,536 & 11,43 \\
\hline $\begin{array}{l}\text { Az élelmiszerekben megtalálható adalékanyagok károsítják az egészsé- } \\
\text { gemet. }\end{array}$ & 4,40 & 0,761 & 17,29 \\
\hline $\begin{array}{l}\text { Az egészséges táplálkozás szempontjából fontos, hogy az ember tisztá- } \\
\text { ban legyen az élelmiszer összetevők (pl. vitaminok, ásványi anyagok, } \\
\text { élelmi rostok) élettani hatásaival. }\end{array}$ & 4,56 & 0,615 & 13,49 \\
\hline \multicolumn{4}{|l|}{ Etikus értékek (Ethical values) } \\
\hline Rendszerint adományokkal támogatom a civil szervezetek munkáját. & 2,47 & 1,396 & 56,52 \\
\hline Évente végzek önkéntes munkát. & 2,07 & 1,396 & 67,44 \\
\hline $\begin{array}{l}\text { Kedvezőbben ítélem meg azt a vállalatot, amelyik jótékonysági akció- } \\
\text { kat támogat. }\end{array}$ & 3,83 & 1,176 & 30,70 \\
\hline $\begin{array}{l}\text { Kedvezőbben ítélem meg azt a vállalatot, amelyik megfelelő munkakö- } \\
\text { rülményeket biztosít alkalmazottai számára. }\end{array}$ & 4,23 & 1,001 & 23,66 \\
\hline Kizárólag állatkísérletektől mentes termékeket vásárolok. & 2,96 & 1,416 & 47,84 \\
\hline \multicolumn{4}{|c|}{ Autentikus értékek (Authentic values) } \\
\hline $\begin{array}{l}\text { Ha a helyi piacokon vásárolok élelmiszert, akkor azzal a magyar terme- } \\
\text { lőket támogatom. }\end{array}$ & 4,36 & 0,790 & 18,12 \\
\hline Fontos számomra a hagyományok tisztelete. & 4,27 & 0,810 & 18,97 \\
\hline $\begin{array}{l}\text { Magyar termékek vásárlásával hozzájárulok az ország gazdasági fejlő- } \\
\text { déséhez. }\end{array}$ & 4,43 & 0,708 & 15,98 \\
\hline $\begin{array}{l}\text { A termékeken szereplő védjegyek (pl. magyar termék) csökkentik a bi- } \\
\text { zonytalanságot a vásárlás során. }\end{array}$ & 4,23 & 0,800 & 18,91 \\
\hline
\end{tabular}

\begin{tabular}{lllc}
\hline \multicolumn{1}{c}{ Individualista értékek (Individualism) } & & \\
\hline Fontos számomra a karrier. & 3,93 & 1,024 & 26,06 \\
\hline A márkás termékeket részesítem előnyben. & 3,68 & 0,904 & 24,56 \\
\hline Az egyedi kivitelezésű termékeket kedvelem. & 3,70 & 0,890 & 24,05 \\
\hline Fontos számomra a stílus. & 4,08 & 0,794 & 19,46 \\
\hline A legújabb divat szerint alakítom életvitelemet. & 3,34 & 1,009 & 30,21 \\
\hline Olyan termékeket vásárolok, amelyek tükrözik személyiségemet. & 3,94 & 0,784 & 19,90 \\
\hline A magas minóségú termékeket kedvelem. & 4,02 & 0,792 & 19,70 \\
\hline TÁPLÁLKozÁsMARKETING & & II. évfolyam, 2015/1. szám
\end{tabular}




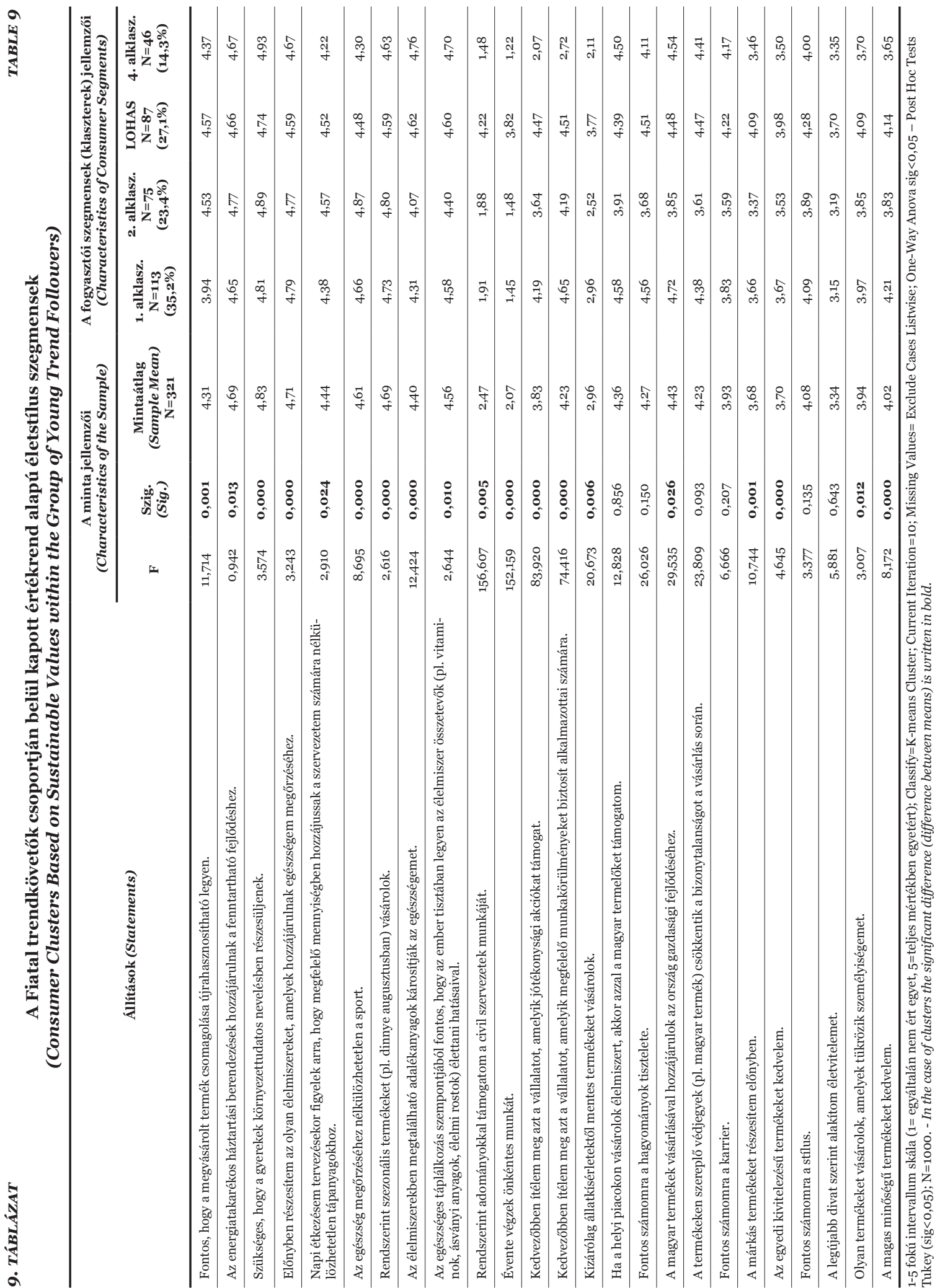


4. KöVETKEZTETÉSEK ÉS JAVASLATOK - Conclunions AND PRoposals

Kutatásunk során a magyarországi LOHAS fogyasztói csoport nagyságának meghatározását tűztük ki célul a fenntartható értékrend szerinti életstílus elemzésével. Eredményeink szerint a magyar fogyasztók értékrendjében jelen vannak a fenntarthatóság irányába mutató jellemzők, és azok hat értékkategóriába különülnek el: individualista értékek, autentikus értékek, környezettudatos értékek, etikus kompetenciaértékek, egészségtudatos értékek, etikus vállalati értékek. Az értékdimenziók közül az autentikus értékek, az egészség- és környezettudatosság, valamint az etikus vállalati magatartás meghatározó jelentőségűek a magyar lakosság számára. Lehota, Horváth \& Rácz (2013) kutatási eredményei szerint a hazai fogyasztók körében a hibrid életstílust kifejező értékek hasonló rendszerben jelennek meg, azzal a különbséggel, hogy esetükben egy faktort alkotnak az egészségés környezettudatos értékek [8].

A fenntartható értékrend mentén öt értékalapú szegmentumot tudtunk elkülöníteni, ezek név szerint az Idősödő közömbösek $(16,4 \%)$, a Fiatal trendkövetők (32,1\%), a Fiatal környezettudatosak (18,6\%), az Etikus hagyománytisztelők (22,6\%) és a Csalódott pesszimisták (10,3\%). Rácz (2013) kutatásai során ettől részben eltérő szegmenseket azonosított: Idős, egészségtudatosak (17\%), Trendkövetők (21\%), Egészség- és környezettudatos patrióták (27\%), Közömbösek (19\%) és a Csalódott pesszimisták (16\%) [13]. Kutatásunkban az Idősödő közömbösek és a Csalódott pesszimisták fenntartható életmód iránti elkötelezettsége alacsony szintű. Az Idősödő közömbösek esetében azonban elmondható, hogy a többi klaszterhez képest az autentikus értékeket felülértékelik. A Fiatal környezettudatosak jellemzően a környezettudatos értékek preferálásában járnak az élen, az Etikus hagyománytisztelők pedig az etikus kompetenciaértékek megítélésében teljesítenek szignifikánsan jobban a többi csoporthoz képest. A legnagyobb klaszter, a Fiatal trendkövetők csoportja körvonalazza leginkább a LOHAS fogyasztók életstílusának jellemzőit. A szegmens azonban nem tekinthető teljes egészében a LOHAS értékek iránt elkötelezett fogyasztói csoportnak. A legnagyobb heterogenitást az etikus kompetenciaértékek mentén mutatják a Fiatal trendkövetők, ezért szükségesnek tartottuk a csoport további szegmentálását a legelkötelezettebb LOHAS fogyasztók arányának meghatározása érdekében. Az etikus kompetencia-jellemzőket leginkább felülértékelő harmadik alklaszter feleltethető meg a magyar LOHAS fo- gyasztói csoportnak. Eredményeink alapján arányuk $8,7 \%$ a magyar lakosságon belül, amely lényegében megegyezik Rácz (2013) megközelítően 8,0\%-os csoportméretével [13].

A nemzetközi gyakorlatban a Natural Marketing Institute (NMI) szegmentációs módszere terjedt el, mely a fogyasztók környezethez és társadalmi témákhoz kapcsolódó attitűdjei, illetve a környezetvédelmi szempontból fenntartható vállalati múködéssel szembeni fogyasztói elvárások alapján becsüli a LOHAS szegmens méretét [10]. Az eltérő szegmentációs technikák nem teszik lehetővé a magyar és a külföldi kutatási eredmények helytálló összehasonlítását, vagyis nem vonható párhuzam a bemutatott értékalapú csoportok és az NMI szegmentációs modelljének segítségével feltárt szegmensek (LOHAS, Naturalites, Drifters, Conventionals és Unconcerned között).

Ennek ellenére azonban elmondható, hogy a magyar és az amerikai LOHAS fogyasztók demográfiai jellemzői hasonlóak. Egyaránt felülreprezentáltak körükben a nők, a felsőfokú végzettséggel rendelkezők és a jobb anyagi körülmények között élők. Eltérés az életkor tekintetében figyelhető meg. Míg az amerikai felmérésben 46,7 év a LOHAS fogyasztók átlag életkora [10], addig Magyarországon inkább a fiatalabb korosztályra (1839 évesek) jellemző a hibrid életstílus. Az eltérés abból adódhat, hogy az értékorientáció korszakváltása a fejlett országokban 10-15 évvel előbb következett be, mint a kelet-közép európai térség országaiban, így Magyarországon is [19]. További vizsgálatokat érdemel, hogy a magyarországihoz hasonló-e a helyzet a többi kelet-európai országban, ahol is a társadalmi és a kulturális háttér sok közös vonást mutat.

Összegezve kutatásunk eredményeit, kijelenthetjük, hogy a magyar fogyasztók értékrendjében a fenntarthatóság irányába mutató jellemzők jelen vannak, és 8,7\%-uk hordozza a LOHAS-ra jellemző hibrid életstílus sajátosságait.

\section{5. ÖSSZEFOGLALÁs - SUMMARY}

Az 1990-es évekig a marketing fókuszában azok a cserefolyamatok álltak, amelyekben a hatalom birtokosa a termelő volt. Az erőforrások korlátozottságának és a környezeti kihívásoknak a felismerésével, a harmadik évezred elején olyan globális kérdések foglalkoztatják a marketing szakembereket, mint a fenntartható fejlődés és a fenntartható fogyasztás. Kutatásunk célja a fenntartható értékrend szerinti életstílus elemzésével meghatározni a magyarországi LOHAS fogyasztói csoport 
nagyságát, melyet három lépésben valósítottunk meg. Elsőként a fenntartható értékrend hazai megjelenését vizsgáltuk faktorelemzés segítségével. Ezt követően elvégeztük a magyar fogyasztók értékrend alapú életstílus szegmentációját k-means klaszterezési eljárás segítségével, végül pedig további szegmentációval megbecsültük a LOHAS értékek iránt legelkötelezettebb fogyasztói csoport nagyságát. Célkitűzésünk volt továbbá, hogy eredményeinket összehasonlítsuk Rácz (2013) azonos módszertannal végzett tudományos munkájának legfontosabb megállapításaival [13]. A kutatás célkitűzéseinek megvalósítására egy 1000 fós országos reprezentatív kérdőíves megkérdezést indítottunk 2013 szeptemberében Magyarországon. Az értékorientált életstílus kutatás során 25 életstílus-állítást fogalmaztunk meg. A 25 állítás 5 tényező mentén került kialakításra [13], amelyek a következők voltak: környezettudatos értékek, egészségtudatos értékek, etikus értékek, autentikus értékek, individualista értékek. Eredményeink szerint a magyar fogyasztók értékrendjében jelen vannak a fenntarthatóság irányába mutató jellemzők, és azok hat értékkategóriába különülnek el: individualista értékek, autentikus értékek, környezettudatos értékek, etikus kompetenciaértékek, egészségtudatos értékek, etikus vállalati értékek. Az értékdimenziók közül az autentikus értékek, az egészség- és környezettudatosság, valamint az etikus vállalati magatartás meghatározó jelentőségűek a magyar lakosság számára. A fenntartható értékrend mentén öt értékalapú szegmentumot tudtunk elkülöníteni, ezek név szerint az Idősödő közömbösek (16,4\%), a Fiatal trendkövetők (32,1\%), a Fiatal környezettudatosak (18,6\%), az Etikus hagyománytisztelők (22,6\%) és a Csalódott pesszimisták (10,3\%). A legnagyobb klaszter, a Fiatal trendkövetők csoportja körvonalazza leginkább a LOHAS fogyasztók életstílusának jellemzőit. A szegmens azonban nem tekinthető teljes egészében a LOHAS értékek iránt elkötelezett fogyasztói csoportnak. A legnagyobb heterogenitást az etikus kompetenciaértékek mentén mutatják a Fiatal trendkövetők, ezért szükségesnek tartottuk a csoport további szegmentálását a legelkötelezettebb LOHAS fogyasztók arányának meghatározása érdekében. Az etikus kompetencia-jellemzőket leginkább felülértékelő harmadik alklaszter feleltethető meg a magyar LOHAS fogyasztói csoportnak. Eredményeink alapján arányuk 8,7\% a magyar lakosságon belül, amely lényegében megegyezik Rácz (2013) megközelítően 8,0\%-os csoportméretével [13].

\section{IRODALOMJEGYZÉK - REFERENCES}

[1] Achrol, R. - Kotler, P.: Frontiers of the Marketing Paradigm in the Third Millennium. In: Journal of the Academy of Marketing Science. 2012. 40 (1) 35-52.

[2] Blankenship, A. B. - Breen, G. E.: State of the Art Marketing Research. American Marketing Association, NTC Business Books, USA, Illinois, 1993.

[3] Clifton, P. - Nguyen, H. - Nutt, S.: Market Research: Using Forecasting on Business. Butterworth-Heinemann, Oxford, 1992.

[4] Cohen, M. J.: Consumer Credit, Household Financial Management, and Sustainable Consumption. In: International Journal of Consumer Studies. 2007. 31 (1) 57-65.

[5] Hofmeister Tóth Á. - Kelemen K. - Piskóti M.: A fenntartható fogyasztás jellemzői és trendjei Magyarországon és a régióban. In: Fenntartható fogyasztás? A fenntartható fogyasztás gazdasági kérdései (Szerk.: Csutora M. - Hofmeister Tóth Á.). AULA Kiadó, Budapest, 2011. 53-76.

[6] International Organisation of Consumers Unions (IOCU): Beyond the Year 2000: the Transition to Sustainable Consumption: a Policy Document on Environmental Issues. IOCU ROENA, The Hague, 1993.

[7] Kotler, P.: Reinventing Marketing to Manage the Environmental Imperative. In: Journal of Marketing. 2011. 75 (4) 132-135.

[8] Lehota J. - Horváth Á. - Rácz G.: A potenciális LOHAS fogyasztók megjelenése Magyarországon. In: Marketing \& Menedzsment. 2013. 47 ( 4) 36-54.

[9] Malhotra, N. K.: Marketingkutatás. Akadémiai Kiadó, Budapest, 2008.

[10]Nielsen, \& Natural Marketing Institute (NMI): Green Consumers Spend More in Warehouse Clubs, and Buy More Produce, Pasta and Cereal than Non-green Consumers. 2008. Nielsen and NMI report. URL:http:// www.nielsen.com/content/dam/nielsen/en_ us/documents/pdf/Press\%20Releases/2008/ June/Green\%20Consumers\%20Spend\%20 More\%20In\%2oWarehouse\%2oClubs,\%20 And \% 2oBuy\%2oMore\%2oProduce, \%20 Pasta\%20And\% 20Cereal\%20Than\% 20 Non-Green\%20Consumers,\%20Nielsen\%20 And\%20NMI\%20Report.pdf (Letöltés dátuma: 2014. március 17.) 
[11] Organization for Economic Cooperation and Development (OECD): Sustainable Consumption and Production: Clarifying the Concepts. OECD, Paris, 1997.

[12] Organization for Economic Cooperation and Development (OECD): Towards Sustainable Consumption Patterns: a Progress Report on Member Country Initiatives. OECD, Paris, 1998.

[13] Rácz G.: Az értékek változásának és a fenntartható fejlődés trendjének hatása a hazai élelmiszerfogyasztásra. Ph.D. értekezés, Szent István Egyetem, Gazdaságés Társadalomtudományi Kar, Gazdálkodás és Szervezéstudományok Doktori Iskola, Gödöllő, 2013.

[14] Sajtos L. - Mitev A.: SPSS kutatási és adatelemzési kézikönyv. Alinea Kiadó, Budapest, 2007.

[15] Scipione, P. A.: A piackutatás gyakorlata. Springer Hungarica Kiadó, Budapest, 1994.

[16] Scott, W. G.: An Introduction to Sustainable Marketing. In: (Ea.: Benigni, C. - Carletto, S. - D'Orazio, E. - Sacconi, L. - Scott, W. G. - Unnia, M.). Etica Pubblica, Finanza, Globalizzazione. Medusa, Milan, 2005. 25-42.
[17] Szakály Z: $\quad$ Záplálkozásmarketing. Mezőgazda Kiadó, Budapest, 2011.

[18]Székely M. - Barna I.: Túlélőkészlet az SPSS-hez. Typotex Elektronikus Kiadó, Budapest, 2008.

[19] Törócsik M.: A tudatos fogyasztást és az egészséget preferáló új fogyasztói trendcsoport a LOHAS csoport megjelenése Magyarországon. In: Élelmiszer, táplálkozás és marketing. 2007. 4 (1) 41-45.

[20]Törő́csik M.: Fogyasztói magatartás Insight, trendek, vásárlók. Akadémiai Kiadó, Budapest, 2011.

[21]World Health Organization (WHO): World Health Statistics 2012. WHO Press, Geneva, 2012.

[22]Z_punkt GmbH: Megatrends. Z_punkt $\mathrm{GmbH}$, The Foresight Company, Köln, Karlsruhe, Berlin, 2008. 